\title{
Paulus er ikke død - han lugter bare grimt. Den aksiale værdiomkalfatrings betydning for tidlig Kristusreligion
}

\author{
ANDERS KLOSTERGAARD PETERSEN
}

Fair is Foul, and Foul is Fair (Shakespeare Macbeth, akt 1, scene 1)

\begin{abstract}
Aldrig har jeg så saa stærkt som hernede følt, hoilken Forbrydelse mod Menneskene Kristendommen er. Aldrig har jeg med en saadan Skamfuldhed forstaaet, hvor dybt vi er sunkne, og hvor højt vi endnu skal tilvejrs for bare at række Skuldrene af den Slægt, hois Menneskestorhed hin blegnæbede Herre fra Nazareth har vovet at mistrnkeliggøre. Kender du Fortællingen om Kong Pukkelryg? Da Skæbnen engang havde villet, at Majestæten var bleven født med skæve Ben og et Knæk $i$ Ryggen, udstedte han en Forordning, der vendte op og ned på Begreberne i Landet. Hvad der var smaat, blev kaldt stort, og hvad der var skævt, kaldtes lige. En rank Ryg kaldtes en Pukkel, Kæmpen en Dværg. -I det forrykte Land lever vi den Dag $i$ dag! ${ }^{1}$
\end{abstract}

\footnotetext{
Pontoppidan, Lykke-Per. Vol. V. Hans store Værk, København, Det Nordiske Forlag, 1901 70f. Uddraget er fra den ottebinds originaludgave, som udkom 1898-1904. Det var imidlertid den stærkt redigerede og forkortede version af Lykke-Per, som opnåede betydelig udbredelse, og som Pontoppidans berømthed i høj grad hviler på. I 1905 udkom allerede en stærkt revideret og forkortet anden-udgave af romanen i tre bind; men det er fjerde-udgaven fra $1918 \mathrm{i}$ to bind, som i dag er den udbredte og læste version af romanen. Her findes tekstafsnittet i vol. 1, 388; men som man kan se ved sammenligning af de to versioner, arbejdede Pontoppidan fortsat med sproget i de senere versioner. F.eks. er "hin blegnæbede Herre fra Nazareth" i fjerde-udgaven skærpet til "hin blegnæbede kastrat fra Nazareth." I gengivelsen af teksten har jeg bevaret oprindelig ortografi.
} 
ENGLISH ABSTRACT: Through a discussion of Dostoevsky's depiction of the death of the staret in Brothers Karamazov I discuss the olfactory channel of communication in religion with the aim in mind to tease apart the underlying ontology pertaining to different forms of religion. The focus is on impurity related to putrefaction in death. Contrary to the understanding represented by the ironic voice of the narrator in Brothers Karamazov, I explore the view holding the saintly person to undergo an olfactory transformation in death changing into a pleasurable aroma and thereby becoming an indexical token of celestial life. From Brothers Karamazov I proceed to examine notions of divine presence and olfactory tokens in ancient Graeco-Roman culture. I use it as a historical foil to analyse Paul's total twisting of the motif in 2 Cor 2, 14-17 and 4, 7-12 in which he portrays himself and his Christ-message as an indexical putrefaction of Christ. Thus, the title of my essay: "Paul ain't dead, he just smells funny." Finally, I discuss the extent to which such an understanding is encompassed by Philippe Descola's notion of the analogistic ontology.

DANSK RESUMÉ: Jeg fokuserer i artiklen på en form for urenhed, som er knyttet til væmmelsen ved ligstank. I første omgang ser jeg på staretsens død $i$ Brødrene Karamasov. Ad den vej bevæger jeg mig tilbage til græsk-romersk antik og drøfter sammenhængen mellem forestillingen om guddommeligt nærvær og velduft. Diametralt modsat denne opfattelse er Paulus' skildring af sig selv og sit budskab som en omvandrende ligstank. Det er den aksiale spænding for fuld udluftning. Endelig diskuterer jeg i hvilket omfang, en sådan opfattelse og billedbrug lader sig rumme inden for Philippe Descolas tanke om analogismen som en af fire fundamentalontologier.

KEYWORDS: Putrefaction; Olfactory impurity; Axial tension; Kosmos religion; Paul as indexical putrefaction; Analogistic ontology

\section{Præludium}

Jeg har for mange år siden været optaget af, hvordan religion ikke mindst i arkaiske eller komplekse byreligioner ofte bruger det olfaktoriske register (dvs. lugtesansen) til ikke alene at etablere forbindelser til den guddommelige verden, men også som et metaforisk cluster til at signalere guddommeligt nærvær. Hvis Israel Knohls The Sanctuary of Silence: The Priestly Torah and the Holiness School fra 2007 i højere grad havde set på selve tempelforgården og dens offerpraksis og i mindre grad på teltbarakken og en særlig teologisering af denne, kunne den ligeså vel have heddet The Temple Forecourt of Odour or Fat Smell. Jhvh vibrerer med næseborene, når han dufter offerrøgens fede lugt. Andre arkaiske guder gjorde ligeså. Tilsvarende gælder i forhold til selve tempelbygningen, hvor det ikke var offerrøgen, men derimod duften af virak og røgelse på guldalteret og vellugten fra forskellige salver påført ved tempelindvi- 
else og af ypperstepræst, der skulle behage guddommen og fatholde gudens tilstedeværelse i templets inderste: The Precinct of Fragrance. ${ }^{2}$ Men hvad sker der med overgangen til aksial eller kosmosreligion, ${ }^{3}$ når tempel-og offerinstitution forsvinder? Fordufter odør som religiøs kommunikationskanal og går det på samme måde med den korresponderende lugtemetaforik? Det kom den til i de protestantiske kirker; men når det gælder olfaktorik som religiøs kommunikation, ser det anderledes ud i den Romersk-Katolske Kirke og de Ortodokse Kirker (såvel vestlige som orientalske), hvor røgelsen indgår som et centralt element i kulten. Her er jeg imidlertid ikke så meget optaget af religiøs lugt som de muligheder for at drive teologisk tænkning, der ligger i duftmetaforikken. Jeg er især optaget af, hvordan lugtmetaforikken bruges i de tidligste former for Kristusreligion. Her koncentrerer jeg mig alene om Paulus, hvor der er så alt rigeligt at tage fat på. ${ }^{4}$ Men for at nærme mig denne fremmede, fjerne og ildelugtende verden, bevæger jeg mig vejen om ad Dostojevskij og Den russisk-ortodokse Kirke. Derfra går jeg videre til et udvalg af græsk-romerske tekster, som tjener til at placere de paulinske forestillinger inden for den kultur- og dermed også religionshistoriske sammenhæng, de blev til i. Dog først et ord om eksisterende forskning inden for feltet lugt og religion.

Der er skrevet forbløffende lidt af mere generel karakter om emnet, når man tager i betragtning, hvor centralt et område det er ikke mindst i forhold til klassiske religioner, hvor det olfaktoriske register er helt grundlæggende både som kultisk element og som derfor også et betydningsfuldt metaforisk felt, man kan gribe til i forskellige sammenhænge, når man skal reflektere over det guddommeliges tilstedeværelse i

2 For en drøftelse af lugt knyttet til templet i Jerusalem ud fra de gammeltestamentlige tekster, se Lundager Jensen 2000, 295-298, 312-314.

3 I modsætning til min kollega Hans Jørgen Lundager Jensen har jeg de sidste par år erstattet udtrykket aksetidsreligion med kosmosreligion. Dels er aksetidsbegrebet tynget af en uheldig idealisme uden fornøden fremhævelse af sammenhængen mellem religionsfornyelse og socio-materiel omverden, dels er kategorien snævert knyttet til et bestemt geografisk rum og en særlig periode, som vanskeliggør dets bredere religionshistoriske anvendelse (for begrebets åndhistoriske baggrund, se særligt Joas 2014). Kosmosreligioner henviser til en ny form for religion, der vokser frem i tæt sammenhæng med en række imperialdannelser, som i forhold til befolkningsheterogenitet, populationsstørrelse og tæthed samt geografisk areal og økonomisk velstand repræsenterer en betydelig større skala end tidligere set. For en mere detaljeret udfoldelse af denne diskussion med estimater i forhold til befolkningstørrelse og tæthed, økonomisk vækst og geografisk areal, se Sanderson 2018, 195-220. Jeg mener grundlæggende, Robert Bellahs evolutionshistoriske skildring af religionshistorien er korrekt; men det vil være en fordel at ændre og derved nuancere hans terminologi, så den dels gøres mere neutral som universel komparationsnomenklatur, dels formuleres i tæt forbindelse med den socio-materielle udvikling, som den religionshistoriske evolution er både en spejling af og en driver i (se hertil grundsynspunktet i Turner, Maryanski, Petersen og Geertz 2017). Det er baggrunden for, at jeg i dag opererer med følgende kategorier: 1) samlerreligion; 2) samler-jæger religion; 3) simpel agerbrugsreligion; 4) kompleks agerbrugsreligion; 5) simpel byreligion; 6) kompleks byreligion; 7) simpel kosmosreligion; 8) kompleks kosmosreligion; 9) simpel globalreligion; 10) kompleks globalreligion. Jeg kan ikke her andet end antyde problemstillingen, men må henvise til en række kommende publikationer for en nærmere drøftelse.

4 I tidligere studier har jeg ikke mindst set på motivet i sammenhæng med forrådnelse og myten om Fugl Fønix, se f.eks. Petersen 1996, 2001 og 2003. 
verden. Kolleger som Jeppe Sinding Jensen $(1983,11)$ og Hans Jørgen Lundager Jensen berører emnet i forhold til hhv. græsk og israelitisk samt judæisk religion. Lundager Jensen især har både i sin disputats (2002), hvor han drøfter aromatik i forhold til tempelkulten, og i studier af de apokryfe Judiths og Tobits bøger (2006) været optaget af problemstillingen; men jeg har ikke fundet nogen, som diskuterer feltet religion og lugt generelt eller i relation til bestemt religionstype. Det klassiske studium om velduft og guddommeligt nærvær er fortsat en væsentlig artikel af Ernst Lohmeyer fra 1919. Navnlig i forhold til samlingen af klassisk græsk-romerske tekster er Lohmeyers studie uovertruffet; men han drøfter også duft i relation til ægyptisk og persisk religion, ligesom han diskuterer det i forhold til israelitisk og judæisk religion, inklusive tidlig Kristus-religion. Helt typisk for den generations forskning er samtlige græske og latinske kildetekster gengivet på originalsprog uden oversættelse. Det kunne man dengang forvente, at den intenderede læser beherskede. Det har så også nok bidraget til, at kun få i dag bruger Lohmeyers artikel som andet end en standardhenvisning. Det er ærgerligt, for der er fortsat meget at hente i den.

Et andet vægtigt studie, som imidlertid udfolder sig i en noget anden teoretisk sammenhæng, er Marcel Detiennes strukturalistiske analyse af Fønix-myten og aromaternes betydning i forhold til de forskellige versioner af myten. ${ }^{5}$ Detiennes bidrag er væsentligt, fordi han mere grundlæggende, inspireret af Lévi-Strauss og ud fra diskussionen af Fønix-myten, søger at etablere fundamentet for en generel undersøgelse af aromater og religion. Inden for et udvalgt græsk eksempel viser han, hvordan en sådan mere omfattende undersøgelse vil kunne tage sig ud. Men det hører fortsat til fremtiden, at nogen tager Detiennes udfordring op i form af f.eks. en generel undersøgelse af religion og aromatik i komplekse byreligioner.

For få år siden udkom endelig Susan Ashbrook Harveys omfattende monografi, Scenting Salvation, der som undertitel har det sigende navn Ancient Christianity and the Olfactory Imagination. Der er tale om et omfattende studie, hvis fortjeneste ikke mindst ligger i fremstillingen af den antikke græsk-romerske oplevelsesverden, som den kristne duftmetaforik filtreredes gennem og fik sin betydning i relation til. Harveys afhandling er ikke mindst fremragende i skildringen af den tætte sammenhæng mellem asketisme og duftmetaforik; men det er ikke et studium af en generel problemstilling, ligesom Harvey heller ikke diskuterer brugen af duftmetaforik i tidlig Kristusreligion i sammenhæng med forskellige religionstyper (byreligion over for komkosmosreligion). Og så begynder jeg ellers min rejse ind i antikkens forunderlige fremmedartede verden gennem en omvej over Dostojevskij.

\section{En helt anden historie om råd og ligstank}

Dostojevskij lader i sin roman Brødrene Karamasov fortællingen begynde med Alekséij Fjódorovitsj Karamasovs tætte forhold til staretsen Sosima. Staretsinstitutionen er særlig for den russisk ortodokse kirke, hvor den betegner en ældre person i klostervæsenet, som tilbedes for sin særlige åndelige kunnen. Der er tale om en karismatisk

5 Detienne 1972, 57-68, særligt 68, hertil Petersen 2001, 193-200. 
figur, der tilskrives særlig evne til at formidle mellem himmel og jord, fordi han gennem asketisk praksis anses for at have opnået direkte visdom fra Gud. Derved fremstår staretsen også som uafhængig af og derfor en potentiel udfordring af det hierarki, der i øvrigt præger det russisk ortodokse klostervæsen. I kraft af sin karismatiske autoritet har staretsen ofte været en torn i øjet på det institutionaliserede klostervæsen, ligesom den folkereligiøse tilbedelse af staretsen hyppigt er blevet set på med mistro af den institutionaliserede kirke og teologien. Det er den klassiske modstilling i religionshistorien mellem en imagistisk og en doktrinær form for religiøsitet, eller mellem folke- og elitereligion med det væsentlige forbehold, at et lejlighedsvis marginaliseret element i elitereligionen nyder en særlig status i folkereligionen. I Brødrene Karamasov får kontrasten imidlertid en særlig prægning, fordi konflikten her skildres som en modstilling mellem den overleverede forståelse i såvel folke- som elitær munkereligion over for en moderne opfattelse, der byder, at den gamle forestillingsverden forkastes.

Netop sådan en skikkelse knytter bogens hovedperson Alekséij eller Aljósja sig til. Derfor bliver staretsens død også et vendepunkt i romanen, idet staretsen som en af sine sidste handlinger sender Aljósja ud af klosteret og tilbage i verden. Han skal være munk i verden og ikke i klosteret (1965, vol. 1, 234; vol. 2, 8). Samtidig bliver staretsens død og i særlig grad hans krops efterfølgende opløsning anledning til den stærkt ironiserende fortællers opgør med folkereligiøsiteten i såvel Den ortodokse Kirke som blandt folk i almindelighed:

Fader Sosimas afsjælede legeme blev før begravelsen behandlet efter ritualet. Hensovede klosterlærde og asketer bliver som bekendt ikke tvættet $\mathrm{i}$ almindelig forstand. "Når en asket går ind til Herren (således står der i det store ritual) bliver hans legeme (af den dertil udvalgte broder) at bestryge med varmt vand, idet der med svampen (en græsk svamp) gøres kors på den hensovedes pande, på hans bryst, på hans hænder, hans fødder og knæ, men derudover intet" (vol. 2, 61).

Staretsen bliver på ny iført sin munkekutte og en kofte, der begge er skåret op i ryggen, så han kan lægges i korsform som en anden Kristus. Hans hoved iføres hætte med et ottetakket kors. Foran ansigtet efterlades hætten åben, men det dækkes med sort kalkdug. Herefter begynder skandalen imidlertid at ind træde, for staretsens krop går - mod al forventning - lige så stille i gang med forrådnelsesprocessen. Med sardonisk bid spidder fortælleren situationens groteskhed:

Og nu til fortællingen: Da stárets'ens afsjælede legeme endnu før daggry var beskikket til begravelsen, lagt i kisten og anbragt i den forreste celle, hans tidligere modtagelsescelle, blev af en af de omkringstående det spørgsmål løseligt henkastet, og næppe en gang bemærket - måske kun af ganske enkelte, som viste det fra sig med stiltiende ræsonnement, at det ville være den rene tåbelighed at tage forholdsregler mod nogen forrådnelse, mod en opløsningens ånd, i en så hellig afdøds legeme; en sådan tåbelighed fortjente blot beklagelse, ja spot, for den svaghed i troen og letsind, der kendetegnede spørgeren. Hér måtte enhver jo vente - lige det modsatte. - Men ikke længe efter middag begyndte de kommende og gående at lægge mærke til noget, som man først kun fornam i tavshed og for sig selv, ja, hver især endog med kendelig angst for at åbenbare andre sin vågnende tanke -men som i den tredje time efter middag allerede ytrede sig 
så afgjort, at efterretningen derom nu som en løbeild bredte sig i eremitgården og blandt hele den store skare pilgrimme, fra disse fór over til klosteret, derfra nåede ind til byen og overalt satte både troende og ikke-troende i den største sindsbevægelse. De ikketroende frydede sig, og blandt de troende var der sandt at sige adskillige, som frydede sig mere, end nogen vantro kunne gøre det; thi "menneskene frydes ved den retfærdiges fald og ved hans skændsel", som den nu hensovede stárets selv havde udtalt i en af sine samtaler med brødrene. -Sagen var denne: fra kisten bredte der sig lidt efter lidt en stadig stærkere ligstank, ved tretiden var den følelig for alle, endog i overordentlig grad, og den tog til minut for minut (Ibid., 65). ${ }^{6}$

Skandalen tager kun til i takt med, at stanken stiger til det uudholdelige. Fortælleren føjer sarkastisk til, at man i grunden måtte undres over den forargelse, ligstanken fra staretsen udløste, eftersom også andre hellige fædre og gudsgrebne staretser efter deres død helt naturligt havde udsendt en forrådnelseslugt og ikke en liflig aroma af himmelsk velduft. Men Sosimas stank bliver en anledning til, at munkenes intriger og splittelser kommer for en dag:

Aldrig så snart var legemets opløsning begyndt at ytre sig utvetydigt, før man allerede af brødrenes ansigtsudtryk, når de trådte ind i den afdødes celle, øjeblikkelig kunne slutte sig til, af hvad grund de kom: man så den ene efter den anden træde ind, blive stående et øjeblik med løftet ansigt og derpå resolut gå ud igen til den ventende skare for snarest at bekræfte den opsigtsvækkende meddelelse. Nogle af de ventende rystede med sørgende mine på hovedet, andre gjorde slet ikke forsøg på at skjule den glæde, der i samme nu glimtede i deres spottende blik. De skadefro var end ikke udsat for nogle bebrejdelser mere, ingen løftede sin røst til noget forsvar, hvad der forøvrigt var sælsomt nok, da de, som forblev den hensovede stárets hengivne, trods alt udgjorde brødrenes flertal: men denne gang var det kun alt for tydeligt Herrens vilje, at mindretallet skulle være det afgørende (Ibid., 67).

Replikskifterne mellem bogens fortalte figurer tager til i skarphed og spydighed, og fortælleren undslår sig ikke for ironisk at svinge religionskritikkens pisk over optrinnet:

"Ja, hvad skal man nu tro om noget sådant," hørte man fra enkelte af munkene, først i en ligesom bedrøvet tone, "hans legeme var jo så lille, det var jo så magert og indskrumpet, kun skind og ben - hvordan kan vel fra dette legeme udgå en sådan stank af opløsning?" - "Ja, heri ligger et særligt tegn fra Gud," tilføjede andre skyndsomst; denne mening blev øjeblikkelig akcepteret uden mindste modsigelse, og man gav den et særligt eftertryk ved følgende ræsonnement: ifald opløsningen var forløbet på naturlig måde, som hos enhver hensovet synder, ville denne lugt først have vist sig på et senere tidspunkt, ikke med en så overraskende hurtighed, efter knapt et døgns forløb. “Nej, den er kommet naturen i forkøbet," sagde man, "nej, dette er Guds eget hellige fingerpeg!" (ibid., 68).

Persiflagen rettet mod staretsen fortsætter; men det lader jeg ligge. Pointen skulle være klar nok: Som hellig og gudfrygtig mand må staretsen i værkets fortalte verden ved sin død ikke gå i forrådnelse. Som himmelstof i verden er den manglende forråd-

6 Jeg har som vanlig bevaret originaltekstens ortografi og tegnsætning. 
nelsesproces et indeksikalt udtryk for staretsens særlige forbundethed med Gud. Omvendt bliver forrådnelse og ligstank et fysisk udtryk for staretsens manglende hellighed. Jeg kender selv traditionen fra både den Katolske og især den Ortodokse Kirke, hvor det er helt almindeligt, at hellige afdøde balsameres og i de doktrinært prægede udgaver bruges som formidlere til Gud og i de mindre dogmatisk stuerene sammenhænge som direkte kilde til tilbedelse. Jeg har også oplevet i ikke mindst ørkenklostre, hvordan hellige mænd hævdes at udsende en særlig liflig aroma, der modsvarer deres hellighed. Helt i tråd med fortællerstemmen hos Dostojevskij kan jeg tilføje, at det nok ikke er tilfældigt, at sådanne hellige mænd og lejlighedsvis kvinder særligt findes i områder, hvor klimaet har en ikke ubetydelig væsentlighed for den helliges aromatiske guddommelighed. Baggrunden for denne tradition skal søges i klassisk arkaisk eller urbanreligion; men den får en særlig karakter i tidlig Kristusreligion, hvor den fra begyndelsen af det andet århundrede forbindes med den voksende martyrkult og ikke mindst martyrlitteraturen. Det tidligste eksempel, jeg har fundet, er Polykarps Martyrium fra antagelig omkring 160 e.v.t. Her hedder det om henrettelsen af Polykarp på bålet (ud fra Musurillos tekst i standardudgaven):

Han (dvs. Polykarp) havde udsendt sit 'amen' og fuldendt sin bøn, og de bålansvarlige antændte ilden. En enorm flamme lyste op. Et under blev givet os, som så det, at skue. Og vi har vogtet over de ting, som skete, for at kunne fortælle dem til andre. Og ilden var som et hvælvet rum i form, ligesom et skibs sejl, når det blæses ud i vinden, omkredsede den martyrens legeme som en ring. Og han var midt i det, dog ikke ligesom kød, der brændes, men som et brød, der bages, eller som guld og sølv, der lutres i en smelteovn. For vi modtog til gengæld også fra det en sådan velduft som duftende røgelse eller andre ædle krydderier (s. 16).

Denne tanke om den hellige mands eller kvindes vellugt i døden står i skærende kontrast til staretsens ligstank. ${ }^{7}$ For værkets hovedperson Aljósja bliver tumulten og stridighederne omkring hans elskede starets død årsag til, at han forlader klosteret for at leve sit liv i verden. Fortællerrøsten griber atter ind og kommenterer historiens gang ved at forholde sig direkte til spørgsmål stillet af fortællingens fortalte figurer:

På fader Paisijs bedrøvede spørgsmål: "Hører du også til de lidet troende?" kan jeg på Aljósjas vegne med bestemthed svare: "Nej, til de lidet troende hører han ikke." Ja, jeg kan endog sige, at nu mere end nogensinde var lige det modsatte tilfældet: hans hele sjælelige forvirring kom just deraf, at hans tro netop var så fast. Men hans forvirring var stor, og alt, hvad der foregik med ham og i ham, var så kvalfuldt, at han selv længe efter mindedes denne dag som en af de tungeste og mest afgørende i hans liv. Men hvis man spørger mig rent ud: "Er det virkelig muligt, at al denne sorg, at al hans dybe sindsoprør kunne stamme alene fra dette, at hans stárets afsjælede legeme, i stedet for straks at få helbredende kraft, lige tværtimod gik i hastig opløsning?" så må jeg uden betænkning svare: "Ja, dette var virkelig årsagen." Blot vil jeg bede læseren om ikke straks af den grund at le ad min unge helt og hans rene sind. Jeg har dog ingenlunde i sinde at bede om undskyldning for ham, at forklare eller retfærdiggøre hans hjertes enfold ved for eksempel at henvise til hans store ungdom eller til hans ringe bevandring

7 Det er dette motiv i kristen martyr- og hagiografisk litteratur, som Harveys monografi giver en detaljeret undersøgelse af. 
i videnskaberne, hans mangel på kritisk sans, osv., osv. Nej, tværtimod, jeg forsikrer min læser, at jeg føler den mest oprigtige højagtelse for hans hjerte, netop således som det er.... (Ibid., 76).

Der er naturligvis meget mere at sige om Dostojevskijs gennemspilning af moderne religionskritik i hans fænomenale epos Brødrene Karamasov. Det fortjener en uddybende og selvstændig behandling; men jeg lader her Aljósja og Dostojevskij være og bevæger mig til en anden form for ligstank med en helt anden grad af radikalitet eller rådden dunst, nemlig Paulus. Den bagvedliggende tanke er den samme som bag forestillingen om Sosimas liflige velduft som himmelsk aroma i en stinkende verden; men værditilskrivningen og motivets religiøse brug sættes helt anderledes på spidsen eller, om man vil, mislugten intensiveres både epistemologisk og ontologisk. Dermed berører jeg også en mere grundlæggende kulturvidenskabelig og vidensfilosofisk problemstilling: Hvilken ontologi forstået som grundlæggende virkelighedsforståelse reflekteres i de forskellige religionsformer. ${ }^{8}$ Endelig udfordrer jeg gennem fremlæggelsen af Paulus' brug af ligstanksmetaforikken Descolas analogistiske ontologi ved at foreslå, at man som mindstemål sondrer mellem forskellige grader af analogisme som ontologi.

\section{Guden er her. Her dufter lifligt}

I klassisk arkaisk religion bruges duft som et indeksikalt udtryk for guddommeligt nærvær. I Euripides' tragedie Hippolyt udbryder den døende Hippolyt: "Men hvad er det? Åh, guddommelig pust af duft. Og skønt jeg er i plager, mærker jeg dig, og min krop lettes. Gudinden Artemis er på dette sted" (Hippolyt 1391-3). ${ }^{9}$ Forud for den første monolog i Aischylos' Den bundne Prometheus har Hephaistos og Kratos begivet sig til jordens fjerneste egne til den forbandede Prometheus, som efter sit guddommelige ran står uafvendeligt bundet i mistrøstig elendighed: “Se mig, hvad jeg en gud lider fra guderne. Se i nåde til mig, hvilke skamfulde lidelser jeg hutler mig igennem i den uendelige tid, jeg må kæmpe (athleusō). Sådan er den skamfulde lænke, som de saliges nye hersker har udtænkt mod mig. Ve, ve, jeg sukker for både den nuværende og kommende smerte uvidende om, hvor enden for disse nødvendige smerter skal opstå" (Prom 92-100). Lidt efter ser Prometheus i det fjerne Okeanos' døtre ankomme

8 Jeg bygger i denne artikel på Philippe Descolas tanke om fire grundlæggende ontologier: (1) totemisme; (2) animisme: (3) analogisme; (4) naturalisme. Se hertil Descola 2013; 2011. Andre tænkere som Eduardo Viveiros de Castro og Tim Ingold kunne også inddrages som repræsentanter for en øget interesse for ontologiske forudsætninger og basalepistemologiske skemaer inden for antropologiske studier; men her koncentrerer jeg mig om Descola. For Descola, se også Lundager Jensen 2016, der meget tilgængeligt viser, hvordan Descolas diskussion af forskellige ontologier kan omsættes i religionshistorien (her i en drøftelse af Genesis' to skabelsesmyter som udtryk for hhv. analogisme og animisme).

9 Oversættelser fra klassiske sprog til dansk er, hvor intet andet er anført, mine egne. Jeg bruger grundlæggende OCL-editioner af klassiske værker. I andre tilfælde anfører jeg udgaven. 
på en bevinget vogn: “Ha, ha! Holdt, holdt! Hvad hører jeg, hvilken duft sendt usynligt til mig fra guddom eller dødelig eller sammenblandet?" (Prom 114f.). Tilhøreren kan ikke være i tvivl. Et guddommeligt nærvær er undervejs.

I den homeriske hymne til Demeter optræder på samme måde duft som et indeksikalt udtryk for guddommelig tilstedeværelse. Jeg gengiver den her i Otto Steen Dues glimrende oversættelse: “Således talte Demeter og ændred sin vækst og sit ydre, afskød hammen af ælde og ånded guddommelig skønhed, og der kom fra hendes klær en berusende vellugt (odmē d'himeroessa thuēentōn apo peplōn), fra hendes evige hud en glans af udødelig guddom" (Hym Hom ad Dem 275-78). Kan duft bruges som udtryk for en guddoms nærvær, kan man selvsagt også lave spas med samme forestilling. Det sker hos den antikke spøgefugl par excellence, Aristophanes, som i komedien Freden spydigt lader Trygaios tiltale gudinden Theoria: "Vær hilset Opōra, og du, Theōria. Hvor smukt et ansigt du har, Theōria. Hvilken ånde; hvor sødt om hjertet; hvor lifligt som friheden for værnepligt og som myrra!" (Pax 523-26). Et er Aristophanes' skæmt, noget andet er den lugt, som hidrører fra de guder, som ikke er menneskene venligt stemt. Hævngudinderne, erinyerne, lugter fælt og udsender en giftig røg. I Aischylos' tragedie Eumeniderne gælder det om erinyerne, som eumeniderne i klassisk tid identificeres med: "Men de (sc. eumeniderne) er uden vinger at se, sorte og helt igennem hæslige. De snorker med frastødende åndedrag. Fra øjnene drypper modbydelige dråber. Og (deres) dragt er ikke sømmelig at frembære for guders billeder eller ind i menneskenes hjem" (Eumenides 51-56). Det er dog trods alt undtagelsen. Det almindelige er sammenkoblingen mellem velduft og guddommeligt nærvær.

Duften som udtryk for guddommelig præsens bliver derfor naturligt også anvendt i forhold til templer og helligdomme, hvor en liflig lugt forstås som et indeks for guddommeligt nærvær. Lukian af Samosata fortæller i sit skrift om Den syriske gudinde (om Atargatis), hvordan det om templet gælder: "Og indeni oplyses det af megen guld og loftet er helt igennem guld. Der udgår en ambrosiastisk duft (odmē ambrosiē) fra det, en sådan som hører Arabiens land til, som møder dig med et kraftigt lifligt pust, medens du stiger op til det, og når du går derfra, svinder det ikke bort, men dine klæder bevarer længe dette pust, og du husker det for altid" (De Syria dea 30, 714).

Helt som i den græske litteratur kan romerske forfattere anvende duft som udtryk for guddommeligt nærvær. I Ovids skrift om den romerske kalender Fasti fortæller han i femte bog om måneden Maj om Flora: "Al ting sluttede; og hun trak sig tilbage til den tynde luft. Duften forblev. Du ville vide, at det var en gudinde" (Fasti V 375f.). Parallelt dermed skildrer Vergil i Æneiden, hvordan Venus åbenbarer sig som vellugt for sin søn Æneas: "Hun vendte sig bort; hendes nakke var skær som blad af en rose, hendes ambrosiske lokker gød himmelsk vellugt i luften, mens hendes kjole smøg sig omkring hendes ankler, og gangen røbede hende som sand Gudinde. Da vidste Aeneas det var hans mor..." (Æneiden I 402-06 - her i Otto Steen Dues uovertrufne oversættelse).

Jeg lader den øvrige latinske litteratur ligge. Den bekræfter til fulde det indtryk, jeg allerede har givet ud fra de græske tekster; men et yderligere felt vil jeg dog gerne 
omkring, før jeg bevæger mig over til drøftelsen af Paulus. Det gælder en række gravindskrifter fra hellenistisk-romersk tid. Gravindskrifter er særligt interessante, fordi de hyppigt i kraft af genre repræsenterer nogle af de mest konventionskonforme forestillinger. De siger ikke nødvendigvis så meget om dem, der har etableret gravstedet; men de er sigende for de grundlæggende kulturelle forestillinger i den sociale sammenhæng, graven er etableret i. Hos Lohmeyer finder man f.eks. følgende latinske gravindskrift: "Her ligger Optatus, et ædelt barn i fromhed, for hvem jeg beder, at asken må blive til liljer og roser" (Lohmeyer 1919, 10). Blomsternes duft er her et udtryk for håbet om et godt liv hinsides omgivet af duftende guder. En noget anden forestilling møder vi i en græsk skrevet gravindskrift fra en klippegrav Cagliari omkring første århundrede eller første del af andet århundrede e.v.t., hvor der ikke er megen plads til tanken om et hinsidigt efterliv: “Gid knoglerne må blive dig til violer, Pōmptilla, og skyde frem som liljer og du må blomstre med skud af rosenblade og sødtduftende krokus og uvisnelig amarant, og må du blive til smukke hvide levkøjeblomster som det var for Narcissus og Hyacinten, den evigt begrædelige, og din blomst opnå en tid blandt efterkommerne" (IG XIV, 607). Der har været skrevet en del om denne indskrift, fordi teksten også fortæller, hvordan Pōmptilla døde i stedet for sin syge mand og gav sig selv på samme måde som Alkestis (jf. Euripides' skuespil af samme navn); ${ }^{10}$ men indskriften er ikke helt klar, når det gælder forståelsen af efterlivet. Håbet er imidlertid, som udtrykt her, at Pōmptilla må leve videre i efterslægten, hvor hun som en guddom i skikkelse af forskellige blomster kan brede sin velduft over efterkommerne. ${ }^{11}$

Forlader vi velduft som pant for guddommeligt nærvær og som udtryk for relation til den himmelske verden og retter blikket mod Paulus, ser tingene temmelig anderledes ud. Men, hævder jeg, denne anderledeshed er alene forståelig i lyset af den forestillingsverden, som vi i det foregående har snuset til.

\section{Paulus er ikke død; han lugter bare grimt}

Jeg retter nu blikket mod 2 Korintherbrev, som i virkeligheden udgør Paulus' tredje brev til menigheden. I 1 Kor 5, 9 henviser Paulus til et tidligere brev: "Jeg skrev til Jer

10 Allerede i tekstens indledning hedder det: “Det er Pōmptillatemplet, Vandrer, hun som ønskede døden i sin mands sted. Hvor sød en ende på livet! Da Philip allerede løsnede lemmernes ånd og nærmede sig Lethe med det yderste af læberne, trådte Pōmptilla frem for sin livsopgivende ægtefælle og modtog hans liv for døden (dvs. sin egen - AKP)" (IG 463, 1-6).

11 Deri er der ikke noget mærkeligt. Opfattelsen af at døden betegner den uafvendelige afslutning af enhver form for liv er helt almindelig i latinske og græske gravinskriptioner, hvor opfattelsens udbredelse også fremgår af det forhold, at der anvendes akronymer som f.eks. nfnsnc (Non fui, non sum, non curo - "Jeg var ikke, jeg er ikke, og jeg er ligeglad") eller s.t.t.l. ("Gid jorden må være dig let!"). En tilsvarende græsk indskrift fra Rom fra det andet eller tredje århundrede e.v.t. lyder: "Jeg var ikke. Jeg blev til. Jeg var ikke. Jeg er ikke. Hvis nogen siger andet, lyver han. Jeg vil ikke være. Dreng, vogt dig for, at du ikke bringer til fald. Tungen opnår dig intet ved hårdt arbejde, når du allerede taler; når du fejler, tilføjer den mange onder" (Peek 1955, 611 nr. 1959). For dødsforståelse og efterlivsforestillinger i århundrederne omkring vor tidsregnings begyndelse, se Martin 1995, 108117, og i særdeleshed Wypustek 2013. 
i brevet, at I ikke måtte blande Jer med utugtige." En række forskere har ledt efter dette brev i den eksisterende korintherbrevskorrespondence. Det gælder f.eks. Johannes Weiß, Robert Jewett og Walter Schmithals, Erich Dinkler og Alfred Suhl - det er ikke en tilfældighed, at størsteparten af de repræsenterede forskere alle er tyskere, som i særlig grad arbejdede med redaktionshistorisk metode. Jeg opfatter imidlertid dette brev som tabt; men det betyder så til gengæld, at det nuværende 1 og 2 Kor. i virkeligheden er 2 og 3 Korintherbrev. ${ }^{12}$ Til forskel fra flertallet af forskere, som fortsat forstår 2 Kor. som sammensat af en række brevfragmenter, der hidrører fra forskellige sammenhænge, betragter jeg brevet som en helhed. Det har selvsagt betydning for, hvor megen vægt man kan tillade sig at lægge på det nuværende brevs retoriske struktur. Jeg opfatter yderligere brevet som symbouleutisk i karakter, dvs. som den særlige variant af den deliberative genre, der er orienteret mod at opnå samdrægtighed og fælles forståelse og praksis i en situation kendetegnet ved de facto eller mulig splittelse og konflikt.

Man kan helt naturligt forstå brevet som et forsvarsskrift i forlængelse af en del af brevets hovedtese, 1, 12-14, hvor Paulus skriver: "For vor ros er denne, vidnesbyrdet om vor samvittighed, at vi i Guds oprigtighed og renfærdighed og ikke ved kødelig visdom, men ved gudsnåde har optrådt $\mathrm{i}$ verden, og så meget desto mere over for Jer" $(1,12)$. Der er ingen tvivl om, at der i brevet indgår et stærkt apologetisk motiv; ${ }^{13}$ men pointen i brevtesen er ikke rettet mod den eller de fortidige begivenheder, der havde med affattelsen af det andet Korintherbrev at gøre (altså det nuværende 1 Kor.). De vedrører i Paulus' optik, må man forstå, et overstået stadie. Det er da også derfor, han bagudskuende kan beskrive det tidligere brev som et tårebrev (jf. 2 Kor 2, 4 og 7, 8), ligesom han i 2 Kor.s indledning, hvor han tematiserer problemerne affødt af 1 Kor., nærmest til ulidelighed gentager et trøste- og lidelsesmotiv (se 2 Kor 1, 3-7). 1 Kor. (men altså de facto det andet brev i korrespondencen) har netop ikke opnået den ønskede virkning, men har givet anledning til yderligere ballade og modstand mod Paulus blandt korintherne. Det fremgår meget tydeligt af næste vers, hvor Paulus tager bladet fra munden over for sine intenderede adressater: “Vi skriver ikke andre ting til Jer, end hvad I selv kan læse og erkende" (v. 13a). Her henviser Paulus netop til de problemer, som affattelsen af 1 Kor. har afstedkommet i menigheden, og som er blevet skærpet, fordi Paulus har stillet sine modtagere et besøg i udsigt, som han af forskellige grunde fortsat har skubbet foran sig og på affattelsestidspunktet for 2 Kor. endnu ikke indfriet (jf. 2 Kor 1, 15-24). Formålet med 2 Kor. er ikke mindst at berede vejen for Paulus' kommende besøg ved at bilægge tvister inden hans ankomst, så han ikke risikerer en offentlig blamage foran menigheden og dermed, foruden ærestabet, en voldsom udfordring af hans særlige Kristusforkyndelse, hvilket igen ville føre til en svækket position over for kredsen af Jesus-apostle. Tilsvarende var tanken i 1 Kor., at brevet dels skulle bilægge de indre konflikter i menigheden, dels skulle eliminere Apollos' indflydelse i menigheden som rivaliserende figur til Paulus.

12 Se hertil Petersen 2011, 51-56, jf. min kommende monografi Testing Trust - Observing Obligation: Indexical Underpinnings of Symbolisation in 2 Corinthians.

13 For en uddybning af apologetiske motiver og apologetiske skrifter per se, se mine artikler 2009; 2015a. 
Derfor lød brevtesen også: “Jeg tilskynder Jer, brødre, gennem vor Herre Jesus Kristus' navn, at I alle må mene det samme, at der ikke må være splittelser iblandt Jer, og at I som årer må være forenede i den samme erkendelse og i samme opfattelse" (1 Kor 1, 10).

I det nuværende 2 Kor. uddyber Paulus sin brevtese ved at appellere til modtagerne om den rette forståelse af hans brev: “Jeg håber, at I vil forstå det (sc. brevet) til fuldkommenhed (heōs telous)" (v. 13b). På ny refererer han til den brudte relation, som dels er bevirket af 1 Kor., dels er opstået som resultat af det lovede besøg, Paulus aldrig har indfriet, ligesom han betoner, at dersom korintherne ikke reagerer på brevet, som han ønsker, vil det have konsekevenser for dem på dommens dag: “Ligesom I også nu har kendt os delvist, at vi er Jeres ros, ligesom også I er vores på vores Herre Jesus' dag" $(1,14)$. Tanken om den delvise erkendelse (apo merous) står i modsætning til målsætningen med brevet, at korintherne opnår den fulde erkendelse af Paulus samt eventuelt hans meddisciple. Ros-motiver udtrykker mere specifikt, hvori denne erkendelse består, nemlig en anerkendelse af Paulus. Det drejer sig antagelig ikke om almen anerkendelse, men en eksklusiv forståelse af Paulus dels som menighedens grundlægger, dels som menighedens eneste 'patron' med fuld hånds- og halsret over menigheden. Når det så er sagt, kan man også gennem brevets retoriske løb konstatere, at Paulus i høj grad er usikker på sine modtagere. Derfor er besværgelsen af modtagerne også så voldsom igennem hele brevet.

I 1, 23 påkalder Paulus ligefrem Gud som vidne på, at det var af hensyn til korintherne selv, at han endnu har afstået fra at gennemføre sit lovede besøg: "Men jeg kalder Gud som vidne ved mit liv (egt. hè emē psuchē), at det var for at skåne Jer, jeg ikke kom til Korinth." Samtidig betoner han, hvordan han ikke er patron i forhold til menigheden: "Vi er ikke herrer over Jeres trofasthed (he pistis), men vi er medarbejdere i Jeres glæde. For I står fast i trofastheden (hē pistis)" $(1,24)$. Det er naturligvis en appel til korintherne, som har karakter af en leflen for dem eller en talen dem efter munden. Det fremgår med al tydelighed af brevets retorik, ligesom det er åbenlyst $\mathrm{i}$ de øvrige Paulus-breve, at Paulus de facto opfatter sig som en, der i forhold til sine menigheder har status som patron. Jeg går ikke her yderligere i detaljer med brevet; men må henvise til andre tidligere og kommende arbejder. I stedet bevæger jeg mig frem til afslutningen af brevets narratio-del $(1,15-2,13)$, der indeholder den del af brevet, som i yderligere detaljer forklarer baggrunden - og dermed legitimerer Paulus' forståelse og hans ærinde med brevet - for den situation, som har ført til misforholdet mellem ham og korintherne. Vi kan se, at det ikke mindst er hele problemstillingen omkring affattelsen af 1 Kor., Paulus' insisteren på rituel udsmidning af den såkaldte sexsynder i 1 Kor 5, ${ }^{14}$ og det ikke indfriede ophold blandt korintherne, som er den primære baggrund for miseren og den betændte situation mellem Paulus og modtagerne. Fra narratio-delen bevæger Paulus sig frem mod bevisdelen (pistis- eller

\footnotetext{
14 Det er i forlængelse af Martin 1995, 168-174, blevet almindeligt i forskningen at betegne personen, som har haft et seksuelt forhold til sin stedmoder, på denne måde.
} 
probatio-delen, ${ }^{15}$ der skal levere bevisbyrden for Paulus' forståelse af sagen. Her begynder det famøse afsnit, som har givet titlen til denne artikel - i en lettere tillempet form, med skyldig henvisning til Frank Zappa in memoriam:

Gud ske tak, som overalt fører os i triumftog (thriambeuonti) i Kristus og gør sin erkendelses vellugt (hè osmè tēs gnōseōs) tydelig gennem os på ethvert sted. For vi er Kristus' velduft (Christou euōdia) for Gud blandt dem, der frelses, og blandt dem, som fortabes; for dem fra død til død, for de andre en lugt fra liv til liv. Og hvem er duelig til dette? For vi er ikke som de mange, som sælger Guds ord som en kræmmervare, men af oprigtighed (eks eilikrineias) taler vi som fra Gud over for Gud i Kristus $(2,14-17)$.

Passagen er langt fra let at tyde. Ser man på forsknings- og oversættelseshistorie, har den også skabt betydelige problemer. Der er dels en mærkelig metaforisk brug, dels en uklarhed om, hvad nøglebegreber betyder. Traditionelt har man forstået afsnittet som udtryk for en sejrsbeskrivelse, hvor Gud fører sin apostel i sejrstog; men det er efter min og enkelte andre nyere forskeres forståelse en eklatant misforståelse. ${ }^{16}$ Verbet thriambeuein refererer ikke til nogen heroisk position i sejrstog eller triumfmarch, men i steder for til den ydmygede og udstilledes status som fangen placeret i et offentligt spotte- og ydmygelsesritual. Ovid nævner i sit værk, Tristesserne (Tristia), hvordan fanger i triumfprocessionerne var dystre og triste (Tr. IV.2, 19-24, 29-34). Sejrsprocessionen (supplicatio) var rituelt nøje fastlagt. Oftest tog senatet initiativ til den, og den var ledsaget af stor glæde og begejstring over sejren. Tempelaltrene på ruten duftede af røgelse, og bærere af røgelseskar gik foran processionen. ${ }^{17}$ Processionen var en indeksikal opvisning og manifestation af det romerske magthierarki med embedsmænd og senatorer til at føre processionen an efter triumfvognen og ledsaget af trompeterer til at skabe den fornødne effervescens blandt tilskuere og deltagere. ${ }^{18}$ Derefter fulgte krigsbytte i form af fanger, standarder fra de besejrede hære, skilte med navnene på de erobrede områder og det mest dyrebare i krigsbytte, jf. foto nr. 1 nedenfor. Derpå fulgte den hvide okse, der skulle ofres, og dernæst udstillingen af politiske og militære ledere blandt de besejrede folk. De måtte typisk bære kæder eller

15 I Paulus-forskningen i særdeleshed og Ny Testamente-forskningen og epistolografi-studier i almindelighed har der de sidste 25 år været en intens diskussion af, i hvilken udstrækning det er berettiget at anvende retoriske kategorier til analyse af breve. Retorikken er møntet på taler, medens brevlitteraturen udgør en anden form for genre, nemlig den skriftlige og selvsagt også en særlig variant af denne, nemlig epistolografien. Ikke desto mindre vil jeg hævde uden her at kunne gå ind i argumentationen, at også den mere officielle brevlitteratur med fordel kan analyseres ud fra grundlæggende retoriske kategorier, fordi brev som f.eks. deliberative og forensiske i høj grad lægger sig op ad konventionerne for hhv. den symbouleutiske og forensiske retoriske genre. For en eksemplarisk fremstilling af dette og ikke mindst en meget overbevisende dokumentation for, hvordan det kan lade sig gøre, se Mitchell 1995.

16 Se navnlig Fitzgerald 1988, 160-164.

17 For processioner i den antikke græsk-romerske verden og til processionen overhovedet som en central, men overset religionsfænomenologisk kategori i relation til navnlig arkaiske eller byreligioner, se Lundager Jensen 2017 og især Petersen 2017, 26-30, hvor jeg diskuterer samme Paulus-tekst som ovenfor, men i lyset af spørgsmålet om procession og parade. For den romerske triumfmarch er Beard 2007 uovertruffet. Det er ganske enkelt fagligt indsigtsfuld forskning og formidlingsmæssig brillant fremstilling, som enhver med interesse og glæde for antikken bør unde sig den glæde at læse.

18 For hele spørgsmålet om rekonstruktion af selve triumfmarchen, se Beard 2007, 72-106. 
reb, så spotten og ydmygelsen fremstod endnu større (se Beard 2007, 107-42) - et markant symbolsk-indeksikalsk eller, om man vil, kulturligt indeks for undertvingelse og underdanighed. Vi har en lang række relieffer overleveret med motiver af netop denne del af triumftoget (se f.eks. Beard 2007, figur 24, 134). De tilfangetagne blev fulgt af lyre- og fløjtespillere, som igen blev fulgt af den sejrende feltherres 'livvagter' (lictores) og som afslutning på processionen og dens hierarkiske klimaks triumfvognen med den triumferende general (jf. foto nr. 2 nedenfor samt Beard 2007, 219-56, hvor hun diskuterer den sejrende feltherres deltagelse i triumftoget og yderligere ritualer knyttet til det med den sigende titel "Playing God."

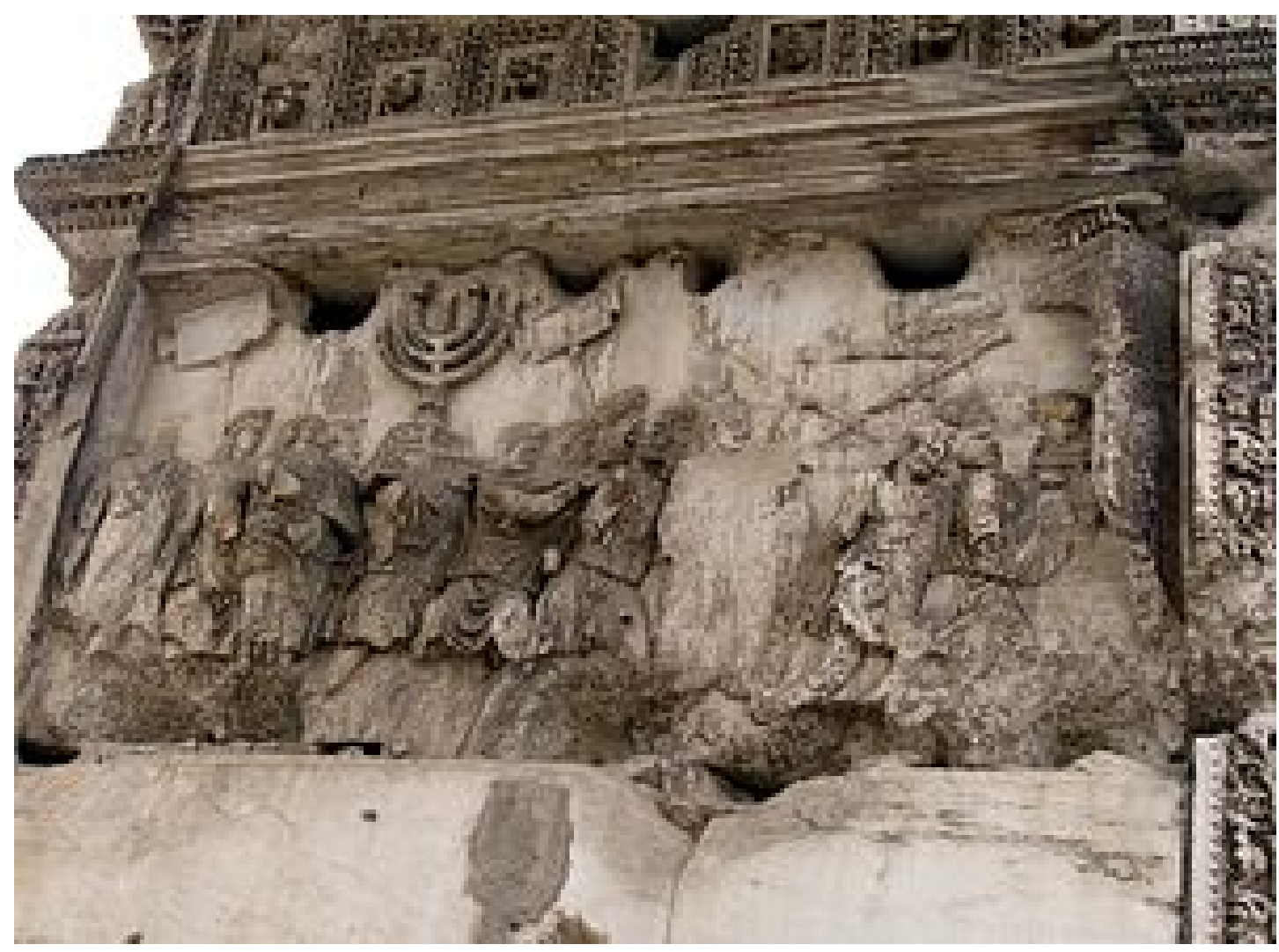

Foto nr. $1 .{ }^{19}$

19 Foto nr. 1: Relief fra Titusbuens indre, der fremstiller det røvede bytte fra romernes erobring af Jerusalem om templet i 70 e.v.t. Den syvarmede lysestage (menorah) er meget fremtrædende i gengivelsen. Foto Wikipedia. 


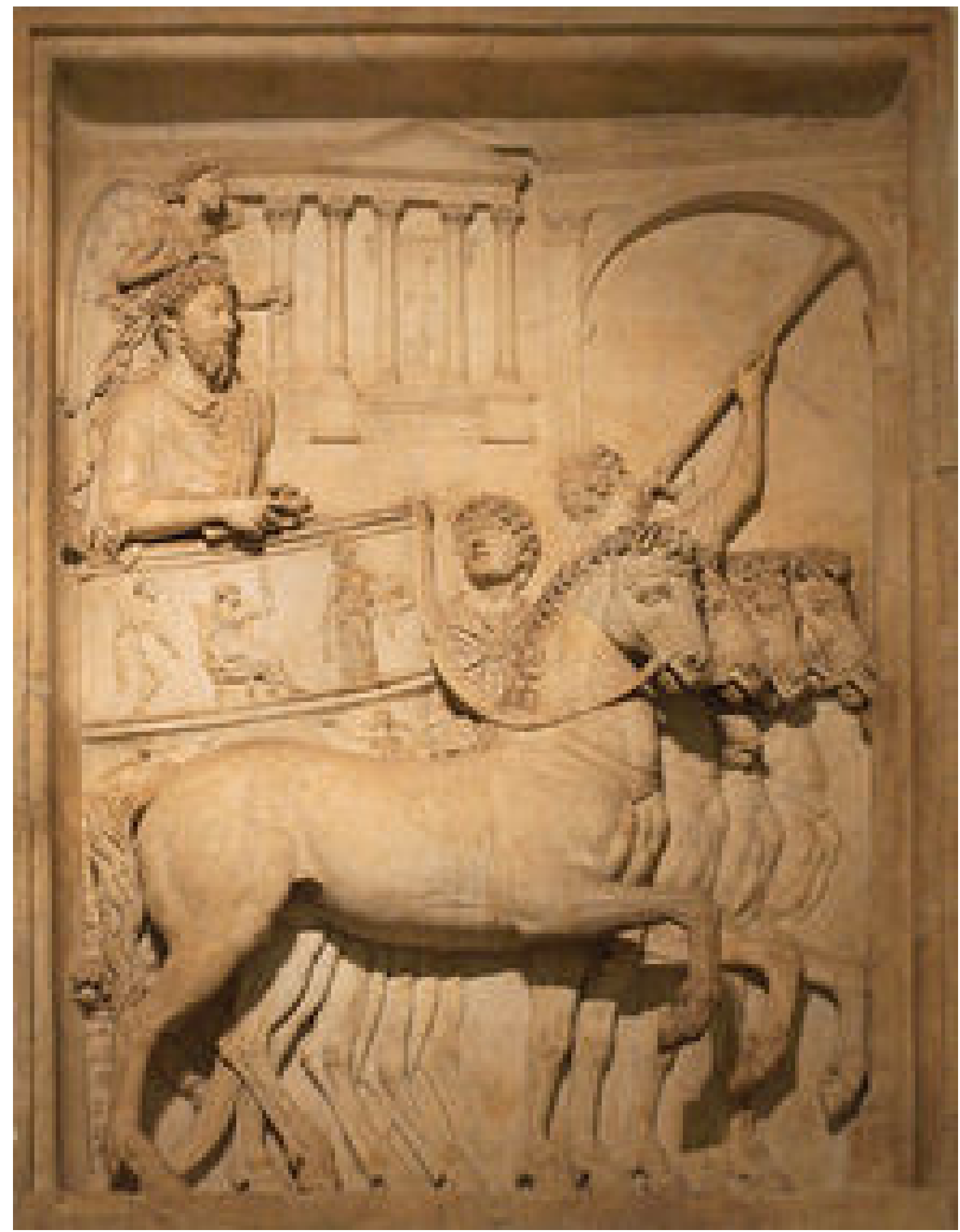

Foto nr. $2 .^{20}$

20 Foto nr.2: Marcus Aurelius i triumfvogn 176-180 e.v.t. i for at fejre hans sejr over germanske og sarmatianske folkeslag (nuværende centrale og sydlige Ukraine, sydlige del af Rusland, Volga-Rusland og sydøstlige Ural, Moldova og det nordøstlige Balkan-område). Kapitolmuseet, Rom, Inv. MC Scu. 808. Foto Wikipedia. Det oprindelige monument (ved Secretarium Senatus på Forum Romanum) er blevet ødelagt antagelig allerede i det syvende årh., hvorefter flere relieffer blev gjort til en del af murværket i Santa Martina (i dag Santi Luca e Martina). To af reliefferne er senere blevet fjernet på 
Det er på grundlag af sådanne forestillinger og repræsentationer, vi skal forstå Paulus' reference til at blive ført i triumftog af Gud i Kristus. Der er ikke nogen form for højstatus involveret i metaforen. Tværtom. Paulus føres af Gud som den nederste i hierarkiet og som udstillet og ydmyget eller, som han skriver et andet sted, "et skue for verden, både for engle og mennesker" (1 Kor 4, 9c). Fra triumfmarchen som billede forskyder Paulus metaforikken til den velduft, som ledsagede triumfmarchen i form af de aromater, der blev båret forrest i processionen. Han forbinder nu vellugt med et kognitivt begreb om, hvordan Gud gennem Paulus' (di' hèmōn, samt eventuelt hans medarbejdere) gør sin erkendelses vellugt tydelig (phanerounti) på ethvert sted. Derved fastholder Paulus en kras kritik dels mod dem, der bagtaler ham i menigheden, dels og især rettet mod den gruppe af rivaliserende forkyndere, som muligvis først er kommet til stede i menigheden efter affattelsen af 1 Kor. (det nuværende) og de problemer, som det brev har forårsaget i menigheden. Til forskel fra dem, der handler i det dulgte (se navnlig kap. 3-4, 6) og i deres egenskab af sofister søger at fravriste korintherne deres penge for den falske visdom, de falbyder, repræsenterer Paulus, i al fald i egen forståelse, $\mathrm{i}$ al åbenhed og manifest (se ikke mindst brugen af glosen parrēsia i 3, 12 og 7,4) den sande erkendelse af Gud. ${ }^{21}$

Denne sammenhæng pointerer Paulus i det følgende vers, hvis nogen ikke skulle have annammet pointen: "Vi er Kristus' velduft for Gud"; men denne lugt, nu i form af velduft (fra osmē v. 14b til euōdia v. 15a), har en kraftig virkning, fordi den sætter skel mellem gruppen, som skal frelses, og flokken, der skal fortabes. Den tanke fører til en ny glidning i metaforikken, at der for den ene gruppe er tale om en ligstank ('en lugt fra død til død'), medens det for den anden gruppe kommer til udtryk som livsalig duft ('en duft fra liv til liv'). Den græske konstruktion (men de) lader imidlertid ikke nogen tvivl om, at ligstanken hører de frelstes gruppe til, medens den liflige duft gælder de fortabte. Hvad i al verden mener Paulus dog med det, og hvorfor føjer han umiddelbart til i v. 16c: "Og hvem er duelig til dette?" (dvs. til at kapere til den skrappe lugt)?

Det er her, spørgsmålet om den aksiale vending eller, hvad Nietzsche betegnede, en Umwertung aller Werte, kommer ind i drøftelsen. Skønt Nietzsche ikke eksplicit anvendte begrebet i Also sprach Zarathustra (1883-91) eller Jenseits von Gut und Böse (1886), indgår forestillingen allerede i hans tidlige værker. Det gælder f.eks. lignelsestalen eller talen om de tre forvandlinger i Also sprach Zarathustra (se KSA iv, 29-31).

ny, hvorefter de indgik i trappeopgangen i Palazzo dei Conservatori. Det særlige ved relieffet er, at det har undergået censur. Oprindeligt var Marcus ledsaget af sin søn, Commodus, men efter hans henrettelse i 192 er han ganske enkelt blevet hugget væk af relieffet. Derfor har templet i dets venstre hjørne for neden fået et mærkeligt omfang, fordi det skal dække for den fjernede Commodus-figur. Statuer og relieffer spillede en helt afgørende rolle i den romerske kejserpropaganda. Over Marcus Aurelius' hoved ses Victoria, sejrsgudinden.

21 For Paulus' brug af begrebet 'ligefrem tale' eller, om man vil, 'åbenmundethed' (jf. 6, 11 to stoma hèmōn aneōigen pros humas Korinthioi - "Vor mund er fuldstændig åben over for Jer korinthere"), se særligt Fredrickson 1996 og Sampley 2003, samt generelt Fitzgerald 1996. Hele denne litteratur dokumenterer meget klart, hvordan Paulus' begreb er snævert knyttet til filosofiske drøftelser tilbage til Platon om den sande filosofs fremtoning og måde at optræde på. Se også i den sammenhæng Malherbes klassiske essay 1989, 67-78. 
Det er dog først i den sene del af forfatterskabet, at Nietzsche begrebsliggjorde tanken med selve udtrykket. Det gælder f.eks. Der Antichrist (KSA vi, 179), Götzen-Dämmerung og i Ecce Homo, hvor det herostratisk berømt hedder: "Aber meine Wahrheit ist furchtbar, denn man hieß bisher die Lüge Wahrheit. - Umwertung aller Werte, das ist meine Formel für einen Akt höchster Selbstbesinnung der Menschheit, der in mir Fleisch und Genie geworden ist" (KSA vi, 665).

Lader vi Nietzsches fnysen og resentiment over for kristendommen ligge (kristendom som livsfornægtelse i form af livsforsagelse og 'folkeplatonisme,' jf. Jenseits von Gut und Böse [KSA v, 11]), mener jeg, at han faktisk har ret i sin observation. Tidlig Kristusreligion kan med rimelighed betegnes som folkeplatonisme i den forstand, at den i sin forestillingsverden og i nogen grad også i sin sociale sammensætning udgjorde en meget bombastisk variant af kosmos- eller aksetidsreligionerne oprindeligt elitære form for tænkning, netop fordi alt her, som i tilfældet med Paulus, blev sat på spidsen. 'Filosofien' eller Kristus-forkyndelsen er hos Paulus blevet degraderet til den tilfangetagnes rolle i triumfmarchen. Og ikke nok med det. Filosoffen og Kristusapostlen udgør i denne verden en omvandrende ligstank, som alene med sin særlige Kristus-forståelse er tilgængelig for gruppen, der skal frelses. Hvor andre dufter liflighed og myrra, lugter Kristus-tilhængeren råd og lig. Lyder det voldsomt? Ja, det er det, for alt sættes her på spidsen.

Hvor de klassiske aksetids- eller kosmosreligioner er analoge i grundlæggende ontologisk forståelse, fordi de forudsætter en lighedstanke mellem det indre og det ydre, mellem himmel og jord, sprænges denne opfattelse i f.eks. tidlig Kristus-religion. Her er der ikke plads til lighed, urform og kopi, oprindelse og afledning som i klassiske aksiale fremstillinger som f.eks. Platons hulelignelse (Staten vii 514a-518b). Pointen er, at afstanden mellem den himmelske verden og den jordiske er så voldsom, at der ikke alene er tale om et brud, men om en kategorial forskel. Guds vellugt kommer i denne verden til udtryk som ligstank, og kun den, som har de nødvendige kognitive forudsætninger skænket gennem et åndsimplantat (helligånden) fra den radikalt anderledes verden, er i stand til at lugte sig til himmelsk liflighed gennem ildelugt. Omvendt er denne verdens parfume og andre liflige aromater for Gud at dufte som ligstank, guden ikke kan bringes i forbindelse med. I den forstand kan man hævde, at de arkaiske eller byreligionernes klassiske tanke om en grundlæggende ontologisk forskel mellem gud og menneske fastholdes, for så vidt guden ikke kan bringes i nærheden af denne verdens goder (se hertil Petersen 2013, 24-28). Men pointen er, at de her vendes om i værdiomkalfatringens totale radikalitet, hvor fair er foul og foul er fair.

Paulus slutter, som vi så, verset med at stille det retoriske spørgsmål: "Hvem er duelig (hikanos) til dette?" Den underforståede pointe er selvsagt, at det er netop kun han selv samt de, der hører ham til i forståelse af Kristus-figuren og i social loyalitet mod ham. Det underforståede gøres meget tydeligt i afsnittets sidste vers, hvor Paulus - foregribende det direkte og eksplicitte angreb på sine modstandere i kap. 10-12 - spidder sine modparter som sofister gennem betoningen af, hvad Paulus netop ikke er: "Vi er ikke som de mange, der falbyder Guds ord som en kræmmervare" $(2,17 a)$. Det er Platons ramsaltede kritik af sofisterne, der her overføres på Paulus' modstandere (se Platon f.eks. Protagoras 312e-315b og Sofisten 221c-224e). Omvendt gentager 
Paulus, hvad han allerede har slået fast i brevets tese (propositio 1, 12b), at han og eventuelt hans medarbejdere taler i renfærdighed som fra Gud over for Gud i Kristus $(2,17 b)$. Dermed har han - retorisk - cementeret sin ethos og med et kraftfuldt pathoselement forsøgt at vække adressaternes afsky over for Paulus' 'modstandere' strengt taget ved vi ikke, om de også forstod sig selv som modstandere af Paulus. Vi ved blot, at han opfattede dem som rivaliserende og fjendtlige forkyndere.

I brevets videre bevisdel (probatio- eller pistis-delen) følger nu en række beviser, der skal give modtagerne de fornødne beviser, så de fælder samme dom, som Paulus i sin tese har lagt op til. I afsnittet 3, 1-6 pointerer Paulus atter som en god filosof, at han med sin foregående argumentation, som vi netop har set på, ikke forfalder til selvros eller praleri, ligesom han heller ikke har brug for anbefalingsbrev udefra i forhold til sin egen person og forkyndelse. Menigheden er - metaforisk talt - selv Kristus' anbefalingsbrev, som betjenes og dermed skrives af Paulus. Ja, ikke nok med det. Der er tale om en ganske særlig form for anbefaling, som ikke er skrevet af blæk, men med den levende Guds ånd, hvorefter metaforikken forskydes til at understrege, hvordan dette anbefalingsbrev ikke er hugget ind i stentavler, men er skrevet på hjerternes kødtavler. I afsnittet 3, 7-4, 6 udvider Paulus motivet i forlængelse af introduktionen af stentavlemetaforikken fra Ex 31-32. Den nye pagt overgår den gamle i henseende til kvalitet - den er livgivende frem for dødbringende, ligesom den er forjættelsesbestemt og ikke dikteret af en forbandelse. Og endelig er den vedvarende frem for efemerisk. Den nye pagt er imidlertid også den gamle overlegen i kvantitet, fordi den besidder en endnu højere grad af herlighed (doksa) - det begreb Paulus i øvrigt bruger til at betegne det stof, som den himmelske verden (og dermed også Gud) udgøres af. Som tjener af den nye pagt handler Paulus hverken i skændighed (jf. den tidligere fremhævelse af oprigtighed og renfærdighed) eller i det skjulte (jf. angrebet på modstanderne for at være sofister, som giver sig ud for at tækkes deres adressater, men de facto søger at føre dem bag lyset og frarøve dem deres penge). Paulus' handlen er åbenlys for både Gud og mennesker. Er hans tale skjult, er den det alene for den gruppe, som netop ikke skal frelses. Her anvendes igen den aksiale grundstruktur til at spidde potentielle indvendinger og faktuelle modstandere. Er de ikke enige med Paulus, skyldes det alene, at de lever i mørke og handler i det dulgte og netop ikke har Gud som fader, men djævelen (jf. 2, 11). Det skjulte i Paulus' forkyndelse består alene i, at han ikke roser sig selv, men alene Kristus. Dermed er angrebet på Paulus for selvros ikke alene afværget, men det er drejet 180 grader rundt, så det egentlige praleri og selvros er, hvad der udgår fra hans modstandere. I afsnittet sidste vers samler han hele tekststykkets grundlæggende modsætninger struktureret om kontrasterne mellem det åbenlyse og det skjulte, lys og mørke, Gud over for denne verden, gudstrofasthed over for troløshed, og Gudslydighed over for selvros og praleri:

Hvis vort evangelium er skjult, er det skjult for dem, som går til grunde, blandt hvilke denne æons gud har blindet de troløses tanker, så de ikke ser lyset, som udgår fra det gode budskab om Kristus' herlighed, han som er Guds billede. For vi forkynder ikke os selv, men Jesus Kristus som herre og os selv som Jeres trælle for Jesus' skyld. For Gud er den, som har sagt: "Der blive lys af mørket," han som har oplyst vore hjerter til forklarelse af den erkendelse, som består af Guds herlig for Kristus Jesus (4, 4-6). 
I det næste store afsnit 4, 7-5, 10 går Paulus over til at drøfte forkyndelsen, vel at mærke den sande. Med baggrundstekst i metaforen i Klagesangene 4 om Zions sønner, der skønt guld er reduceret til lerkar, videreudvikler Paulus den aksiale vertikalspænding (himmel vs. jord) på dybdeaksen som en modsætning mellem det ydre og det indre. ${ }^{22}$ Paulus' forkyndelse er som en skat i lerkar. Den modstilling mellem styrke og svaghed er et emblematisk forhold for, hvordan Guds krafts vælde manifesteres under modsat fortegn i denne verden og mest prægnant, hvordan den netop ikke hidrører fra mennesker (in casu som den sofistiske selvros og praleri, Paulus skyder sine modstandere i skoene) $(4,7)$. Derpå følger et lidelseskatalog, ${ }^{23}$ som imidlertid suppleres af pointeringer af, hvordan de forskellige lidelser ikke fører til opgivelse og mismod på Paulus' side:

Overalt er vi i trængsler, men vi er ikke indestængte, vi er i vildrede, men ikke desperate, vi forfølges, men er ikke forladte, vi slås ned, men slås ikke ihjel, overalt bærer vi omkring på Jesus' dødelse i legemet (tên nekrōsin tou İesou en tō sōmati hēmōn peripherontes), for at også Jesus' liv må være tydeligt i vort legeme. For overalt overgives (paradidometha) vi, de levende, til døden for Jesus' skyld, for at også Jesus' liv må være tydeligt i vort dødelige kød. Så at døden virker blandt os, men livet blandt Jer (4, 8-12).

Det er en kompleks tekst med flere udfordringer. Det centrale tema drejer sig fortsat om konflikten mellem Paulus og modtagerne og i den sammenhæng Paulus' overlegne position i forhold til adressaterne: "Så at døden virker i os, men livet i Jer" (v. 12). Umiddelbart er det ikke til at se, at der er tale om en særlig privilegeret positionering af Paulus over for modtagerne; men det fremgår netop af værdiomkalfatringen, som indebærer en omvending af gængse værdier. Det er imidlertid yderligere kompliceret, fordi Paulus også anvender en tradition, som i en markant strømning af den filosofiske tradition (stoicisme og populærfilosofi) forbindes med høj status. Den virkelige sophos eller vise er den, som er i stand til at modstå lidelser. Hos Epiktet hedder det ligefrem, at det er "lidelserne (hai peristaseis), som viser mændene (i form af deres sande værd)" (Diatriber I xxiv 1). Det ses allerede i Platons skildring af Sokrates' afsked med livet, hvordan Sokrates er i stand til at udøve selvkontrol og besindighed konfronteret med døden. Der er samme tradition, der ligger bag den lukanske skildring af Jesus på korset, hvor han i modsætning til den markinske og matthæanske fremstår som en ædel filosof, som har fuldstændig kontrol med situationen: "Fader, i dine hænder overgiver jeg min ånd" (Luk 23, 46). ${ }^{24}$ Et andet sted i Epiktets Diatriber hedder det om den vises evne til at modstå modgang:

"Vil du have mig til at udholde fattigdom?" Kom med den og du vil indse, hvad fattigdom er, når den finder en dygtig skuespiller (dvs. til at udfylde rollen AKP). "Vil du have mig til at beklæde et embede" Kom med det. Vil du have mig til at miste et embede (anarchia)?" Kom an med det. "Men vil du også have

22 For denne diskussion, se især min artikel 2015b, 71-89.

23 For peristasekatalogerne og deres tætte relation til ikke mindst stoisk filosofi, se navnlig Ebner 1991 og Fitzgerald 1988 samt min egen artikel 2005, 55-58.

24 Se min artikel i WA 2014. 
mig i byrder (ponos)?" 25 Kom an med byrder (ponos). "Hvad så med eksil?" Hvor jeg end går, vil det gå mig godt dér. For også her var det ikke i kraft af stedet godt for mig, men på grund af meningerne, som jeg vil tage med mig. For ingen kan fjerne dem, men de er mine eneste og de kan ikke tages væk. De er mig tilstrækkelige, hvor jeg end er og hvad jeg end gør. "Men det er tid til at dø." Hvorfor siger jeg 'd $\emptyset^{\prime}$ ? Gør ingen tragik (mē tragōdei) ud af sagen, men sig det, som det er. "Det er nu tid til, at det stof, som du er gjort af, kan genoprettes til, som det kom af." Og hvad er frygteligt ved det? (Epiktet Diatriber IV vii 13-15).

Den sande stoiker er den, "som skønt syg er lykkelig, som skønt i fare er lykkelig, som skønt døende er lykkelig, som skønt dømt til eksil er lykkelig, som skønt i vanære er lykkelig. Vis (mig) ham! Ved guderne, jeg længes efter at se en sådan stoiker" (Epiktet Diatriber II xix 24); men som Seneca ædrueligt pointerer, er den sande vise lige så sjælden som Fønix-fuglen (Ep. 42, 1, jf. Epiktet Diatriber II xix 25). Det er på denne baggrund, Paulus' henvisning til lidelser skal forstås; men den får et særligt twist ved at knyttes til tanken om kontrasten mellem det ydre og det indre i relation til forkyndelsen. Paulus' optræden og den særlige måde, han håndterer sine lidelser, er et indeksikalt udtryk for, at hans kraft netop ikke hidrører fra ham selv, men har sin oprindelse hos Gud. Ja, faktisk er Paulus' optræden det, både han selv og en række stoiske filosoffer kunne tale om som et skue(spil) for verden (jf. 1 Kor 4, 9; Seneca Ep 64, 6; De providentia 2, 9; Epiktet Diatriber II xix 25; III xxii 58-59). Trods trængsler og lidelser mister Paulus hverken modet eller slås ihjel; men det dødsnære og lidelsesfyldte har en særlig pointe. Det er knyttet til Jesus' liv, som derved tydeliggøres i Paulus' legemlige fremtræden. Eller sagt på anden vis: Paulus er i bogstaveligste forstand - selvsagt etableret gennem den metaforiske forbindelse - en omvandrende korsfæstelsesfigur, der netop derved indgår i et tæt lidelsesfællesskab med Jesus. Ja, lidelsesfællesskabet er så stærkt, at Paulus kan genanvende den tidligere duftmetaforik til at sige, hvordan han i sin forkyndelse er omdannet til en omvandrende Jesus' ligstank: “For altid bærer vi Jesus' dødelse frem i vort legeme" (v. 10). Det græske ord for dødelse, nekrōsis, betegner selve den dødsproces, som jeg indledte denne artikel med at skildre ud fra Sosimas afdøde legeme. Det er med andre ord forrådnelsesprocessen, Paulus henviser til (se Fitzgerald 1988, 177f.). Denne pointe tydeliggøres yderligere af udtrykket peripherontes, "vi bærer frem," som er det almindelige græske udtryk for 'kiste- eller bårebærere.' Paulus som omvandrende dødsforrådnelse og ligstank er imidlertid ikke metaforisk tilstrækkeligt. Duften intensiveres i v. 11, hvor Paulus sidestiller sin forkyndelse med det selvrefleksive offer, som han også forstår Jesus' korsdød som: "For altid overgives (paradidometha) vi de levende for Jesus' skyld, for at også Jesus' liv må være tydeligt i vort dødelige kød." På den måde er Paulus ikke blot en ligopløst Jesus, men også Jesus-imitator i selve korsfæstelseshandlingen. Hans

25 Det græske ord ponos ('byrde,' 'møje,' 'arbejde' eller 'besvær') er i den græske tradition en terminus technicus for de byrder, som Herakles bar i forbindelse med sine 12 opgaver for kong Eurystheus, Dodekathlos. Se hertil Ebner 1991, 162-165. 
forkyndelse er netop at forstå som en korsfæstelse, hvor askesen og imitationstanken tages til en ny ekstrem. ${ }^{26}$

Men igen er det vigtigt at pointere, at Paulus bruger dette metaforiske cluster til et ganske specifikt retorisk formål, der drejer sig om statuspositionering i forhold til modtagerne og til deres orientering mod andre forkyndere. Når det til sidst $i$ afsnittet fremhæves, hvordan døden virker hos, hvis ikke ligefrem i, Paulus, og at livet virker blandt modtagerne, har værdierne skiftet betydning. Liv er død, og død er liv. Fair is foul, and foul is fair. Naturligvis er liv godt; men korinthernes liv (også som eufemistisk udtryk for deres frelse) kan alene opretholdes og vindes under forudsætning af Paulus' Jesusidentiske offer for dem i sin forkyndelse. Derfor skylder de også Paulus fuld lydighed og trofasthed, der blandt andet skal komme til udtryk i, at de gør sig fri af deres utugt med andre forkyndere og vender tilbage til Kristus som deres retmæssige mand (11, 2-4). Paulus er i denne sammenhæng forloveren, som har ført korintherne sammen med Kristus som manden; men igen skal man passe på med ikke at lade sig forlede af metaforikken. For Paulus er, som vi har set, samtidig den tilstedeværende Kristus i menigheden. Så troløshed mod Kristus er selvsagt ulydighed mod Paulus, og det er denne manglende loyalitet, der gennem brevet skal bringes til ophør ved, at modtagerne føres til det punkt, hvor de har forstået (og handler, vel at mærke) til fuldkommenhed (jf. brevtesen $(1,13 b)$.

\section{Konklusion og besindelse på aksialitet, tidlig Kristusreligion og analogismen som ontologi}

Philippe Descola har i flere værker søgt at kortlægge en universel typologi over de ontologier, som har præget menneskehedens historie. ${ }^{27} \mathrm{Jeg}$ forholder mig her alene til hans drøftelse af den analogistiske ontologi, som er den relevante i forhold til aksetids- eller kosmosreligioner. Analogismen er grundlæggende bestemt ved forskel både i relation til det indre og til det ydre $(2013,122)$. I sin sammenfatning af analogismen betoner Descola, at den oplagte figur makro- vs. mikrokosmos ikke er tilstrækkelig til at indfange den analogistiske ontologis grundstruktur (Ibid., 217):

However, only analogical ontologies have managed to systematize these straggling chains of meaning [som f.eks. mellem biologi og naturomverden udtrykt i relationen mellem menneskekrop og årstider, AKP] into ordered and interdependent sets that for the most part are designed to be effective practically: ways to cope with misfortune, the orientation of buildings, calendars, predestination, eschatology, divinatory systems, the compatibility of marriage partners, good government - everything is interconnected in a web so dense and so charged with consequence that it becomes impossible to tell whether it is man who reflects the universe or the universe that takes man as its model. Chains of transitive causality so long and so luxuriant are seldom to be found in animist or totemic ontologies, and in present-day naturalism they appear only as incomplete

26 Se hertil min artikel 2016, 21-29 samt 2013.

27 For en introduktion til Descolas arbejder, se Lundager Jensen 2016, og for Descola selv særligt 2013 og den lettilgængelige 2011-bog. 
fragments, nostalgic survivals from an enchanted epoch on which horoscope watchers, adepts of alternative medicines, and the followers of New Age sects all tend to draw (ibid. 217f.).

Descola pointerer, at mikro-makro-kosmos-modellen er belastet af, at den prioriterer mennesket som hermeneutisk omdrejningspunkt for de etablerede analogier; men, og det er den afgørende pointe, der er ikke noget basalt antropomorft ved analoge systemer (Ibid., 218). Descola fremhæver også, hvordan analogistiske kollektiver til forskel fra totemistiske, som er nødt til foretage en i bogstavligste forstand selvprojektion for at etablere en forbindelse til omverdenen, alene er systemimmanente (ibid., 400):

The proliferation of particularized entities with dissimilar components that analogism sets in order, and the multiplicity of graduated differences that result from this, are tempered by an obsession to detect common features, signs of correspondences and themes of agreement, for these are the bases of the general system of a segmented hierarchy from which no singularity can be left out (ibid., 400).

Analogismen som ontologi etablerer relationer mellem i udgangspunktet vidt forskellige størrelser og skaber kontinuitet, hvor der ingen kontinuitet er, fordi intet kulturelt fællesskab eller individ kan leve med den totale fragmentering og atomisering:

A world saturated with singularities is almost inconceivable and is in any case extremely inhospitable; so among its premises analogism must include the possibility of modifying that infinitely teeming mass of ontological differences by means of a reassuring continuity that is ceaselessly woven together by correspondences and analogies between its disparate elements (Ibid., 235).

Med den korte præsentation af Descolas forståelse af analogismen som ontologi vender jeg tilbage til Sosimas afsjælede legeme i klosteret og fortællerstemmens ironiske fremstilling af episoden. Fortællerrøsten repræsenterer den naturalistiske ontologis latterliggørelse af analogismens 'folkereligiøse' relationstænkning, staretsens ideelle vellugt som indeksikalt udtryk for transformationen til himmelsk aromat. Det skulle være klart nok; men det centrale spørgsmål er, hvor det efterlader den form for radikaliseret analogisme, som tidlig Kristusreligion er udtryk for. Hvis smuk er styg og styg er smuk, som Shakespeare formulerede det i Macbeth, kan man så overhovedet fortsat tale om en analogistisk ontologi? Og hvad med i den sammenhæng de lidt senere gnostiske former for Kristusreligion, hvor spændingen mellem denne og den anden verden er spændt til bristepunktet gennem pointeringen af kontrasten mellem skabergud og den sande verdens gud? Jeg kan også formulere det på en anden måde. Er der i den descolaske totalontologi, der rummer de fire grundontologier totemisme, animisme, analogisme og naturalisme, plads til den form for religiøst verdensbillede, der insisterer på en radikale dualisme mellem himmel og jord?

Det er ikke umiddelbart indlysende; men måske kan man åndshistorisk opfatte radikaliseringen af kontinuitetstanken i den analogistiske ontologi, som den f.eks. kommer til udtryk i Paulus' metaforer om ligstank og velduft, som en bevægelse frem imod en naturalistisk ontologi. Man kunne i så fald revitalisere Karl Löwiths tanke om en tidlig form for sekularisering i dele af den græsk-romerske og navnlig kristen 
antik (1953). Men det er jeg også forbeholden over for, fordi det alene retrospektivt fremstår meningsfuldt at begribe radikaliteten i modstillingen mellem guddommelig og menneskelig verden som en begyndende sekularisering. At tage vertikalspændingen i tidlig Kristusreligion og identificere den med en proleptisk naturalisme forekommer mig vidtløftig, fordi man derved sammenblander en senere naturalismes skelnen mellem natur og kultur med sondringen i tidlig Kristusreligion mellem himmel og jord; men en 'hellig baldakin' er nu en gang ikke det samme som en jernhård videnskabeligt forstået natur, og en religiøst tolket jord er heller ikke identisk med en naturalistisk udpegning af kultur. Snarere skal man se tidlig Kristusreligion som en ekstrem form for analogisme, der i sin pointering af spændingen mellem denne og den anden verden ikke viste sig at have holdbarhed over tid. Jo mere frelsesaspektet fremhæves i frelsesreligionen, desto vanskeligere bliver det at fastholde relation til skabelse og livets velsignelser. Ekstrem frelsesreligion er for de få og over tid dømt til forfladigelse eller verdsliggørelse. Det er fortællingen om staretsens legeme, på den ene side, over for Paulus' som en omvandrende ligstank af Jesus, på den anden side, et billede på. Den sidste havde ingen gang på jorden, den første genopstod i Kristusreligionen allerede fra det andet århundrede og frem.

Jeg vender så afslutningsvis tilbage til Descola og spørgsmålet om den type ontologi, der repræsenteres af den paulinske forståelse. At give den en selvstændig rolle som distinkt ontologi har jeg svært ved at se en pointe i, fordi der netop, som jeg har argumenteret for, er tale om en undertype. I den forstand nuancerer den snarere end underminerer Descolas fire hovedontologier. At omtolke den ontologi, der reflekteres i den paulinske forståelse, fra analogisme til naturalisme, sådan som man ifølge en klassisk sekulariseringsteori måtte mene, kræver i min optik en forståelse af sekularisering, der slet ikke i fornøden grad tager hensyn til sekularisering som et moderne fænomen. Det vil sige, at man i så fald tilbageprojicerer en sekularisering til en historisk situation, hvor man uden tilstrækkelig besindelse på den socio-kulturelle kontekst fokuserer på et overfladefænomen og betegner det sekularisering. Efter min mening skal man snarere tale om den som en form for radikalanalogisme, som hører kulturens udstigere og dermed også de få til. Dermed er dens historiske succeshistorie også beseglet. Den er de sociale entreprenørers og få åndelige bjergbestigeres særlige variant af den analogistiske ontologi, ${ }^{28}$ der fastholder analogismens grundlæggende kontinuitetstanke, men til forskel fra en monistisk analogisme spaltes den i en analogistisk binaritisme. Helt som i analogismen er enkeltfænomenerne ikke singulære, men del af et kosmos bestemt af forbundne relationer. Til forskel fra den monistiske analogisme insisterer den binaritistiske analogisme som variant og inversion af den første på et dobbeltkosmos, hvor ethvert enkeltfænomen enten er en spejling af

28 Med denne formulering sender jeg en skyldig tak til Sloterdijk, som i sin 2009-monografi fremhæver sammenhængen mellem askese, verdensudstigning og bjergbestigning. Bjergbestigningsmetaforikken (Mount Improbable) bliver hos ham et metaforisk udtryk for individuelle grænsesprængeres evne til at trække den øvrige kultur mod nye højder, hvorved hele samfundets barre forstået som forestillingsevnen til, hvad man kan nå, løftes. Se Sloterdijk 2009, 276-281, og Lundager Jensens Sloterdijkartikel fra 2013. 
den gode og guddommelige verden eller en refleksion af den bøse og djævelske væren. Mellem disse kan der ikke bestå nogen forbindelse. Er denne verden grundlæggende en spejling af det bøse kosmos, må den guddommelige sfære nødvendigvis optræde under modsat fortegn af det, som kendetegner denne verden. Det er denne baggrund, der gør den analogistiske binaritisme revolutionær, magtudfordrende og verdensomstyrtende. Den hører derfor også til undtagelserne og dukker alene op med mellemrum, når folk i grænseområderne (intellektuelt, økonomisk, socialt, politisk, religiøst, etc.) ser sig nødsaget til at reformere magtelitens centrum. Som sådan lever den videre, men kun for kortere perioder ad gangen: En rank ryg kaldes en pukkel, kæmpen en dværg, og kunne man tilføje, pukkelryggen en ædel figur, og gnomen en gigant. Og just derfor er rent urent, og urent rent. For Paulus er ikke død; han lugter bare grimt - en gang imellem.

\section{LITTERATUR}

Beard, Mary

2007 The Roman Triumph, Cambridge, MA: The Belknap Press of Harvard University. https://doi.org/10.4159/9780674020597

Descola, Philippe

2011 L'ecologie des autres: L'Anthropologie et la question de la nature, Éditions Quæ, Liège.

2013 Beyond Nature and Culture, oversat af Janet Lloyd, The University of Chicago Press.

Detienne, Marcel

1972 Les Jardins d'Adonis. La Mythologie des Aromates en Grêce, Paris: Gallimard.

Dostojevskij, Fodor

1965 Brødrene Karamasov I-III, i Dostojevskijs samlede værker oversat af Ejnar Thomassen vol. 3-5, København: Stig Vedelkærs Forlag.

Ebner, Martin

1991 Leidenslisten und Apostelbrief. Untersuchungen zu Form, Motivik und Funktion der Peristasenkataloge bei Paulus, Forschung zur Bibel vol. 66, Würtzburg: Echter Verlag.

Fitzgerald, John T.

1988 Cracks in an Earthen Vessel. An Examination of the Catalogue of Hardships in the Corinthian Correspondence, SBL Dissertation Series 99, Atlanta, GA: Scholars Press.

Fitzgerald, John T., ed.

1996 Friendship, Flattery, and Frankness of Speech: Studies on Friendship in the Ancient World, Novum Testamentum Supplementum vol. 82, Leiden: Brill. https://doi.org/10.1163/9789004267282

Fredrickson, David E.

1996 “П

Harvey, Susan Ashbrook

2006 Scenting Salvation. Ancient Christianity and the Olfactory Imagination, The Transformation of the Classical Heritage XLII, Berkeley, University of California Press.

Homer

2005 Homers hymne til Demeter, oversat af Otto Steen Due, København: Gyldendal.

Jensen, Hans Jørgen Lundager

2000 Den fortærende ild. Strukturelle analyser af narrative og rituelle tekster $i$ Det gamle Testamente. Aarhus: Aarhus University Press.

2006 "Family, Fertility, and Foul Smell," i: Mark Bredin (ed.), Studies in the Book of Tobit: A Multidisciplinary Approach, London: Bloomsbury, 129-139. 
2013 "Udstigere og immunsystemet, asketer og akrobater. Om Peter Sloterdijks Du mußt dein Leben ändern. Über Anthropotechnik," Religionsvidenskabeligt Tidsskrift 60, 75-97.

https://doi.org/10.7146/rt.v0i60.20411

2016 “Ontologier i Det Gamle Testamente: Analogisme og Animisme (Gen 1 og Gen 2-3)”, Collegium Biblicums Årsskrift 20, 1-19.

2017 “Processioner: Indledning," Religionsvidenskabeligt Tidsskrift 66, 3-13. https://doi.org/10.7146/rt.v0i66.26445

Jensen, Jeppe Sinding

1983 "Honningsøde Orfeus. En oversigtsartikel: Klassikerne, socialantropologien og den strukturalistiske myteforkning," Religionsvidenskabeligt Tidsskrift 2, 7-25.

Joas, Hans

2014 Was ist die Achsenzeit? Eine wissenschaftliche Debatte als Diskurs über Transzendenz, Basel: Schwabe.

Knohl, Israel

2007 The Sanctuary of Silence. The Priestly Torah and the Holiness School, Winona Lake, IN: Eisenbrauns.

Lohmeyer, Ernst

1919 “Vom göttlichen Wohlgeruch," Sitzungsberichte der Heidelberger Akademie der Wissenschaften. Philosophisch-historische Klasse 9, Heidelberg: Carl Winters Universitätsbuchhandlung, 3-52.

Löwith, Karl

1953 Weltgeschichte und Heilgeschehen. Die theologischen Voraussetzungen der Geschichtsphilosophie, Stuttgart: Kohlhammer Verlag.

Malherbe, Abraham J.,

1989 Paul and the Popular Philosophers, Minneapolis, MN: Fortress Press.

Martin, Dale B.

1995 The Corinthian Body, Yale University Press.

Mitchell, Margaret M.,

1991 Paul and the Rhetoric of Reconcilliation: An Exegetic Investigation of the Language and Composition of 1 Corinthians, Hermeneutische Untersuchungen zur Theologie vol. 28, Tübingen: Mohr-Siebeck.

Musurillo, Herbert

2000 Acts of the Christian Martyrs. Volume II, Oxford: Clarendon Press at Oxford University.

Nietzsche, Friedrich,

1988- Kritische Studienausgabe (anden udg. [1980]) ved Mazzino Montinari \& Giorgio Colli, eds., Berlin: DeGruyter.

Peek, Werner

1955 Griechische Vers-Inschriften. Band I. Grab-Epigramme, Berlin: Akademie-Verlag.

1960 Griechische Grabgedichte. Griechisch und Deutsch, Schriften und Quellen der alten Welt 7, Darmstadt: Wissenschaftliche Buchgesellschaft.

Petersen, Anders Klostergaard

1996 “Fra opstandelsessymbol til messiansk dessert," Fønix 4, 239-257.

2001 “Fønix mellem tradition og nybrud. Inkulturationsproblemet i tidlig kristendom," Dansk Teologisk Tidsskrift 3, 189-212.

2003 "Between Old and Novelty: The Problem of Acculturation of Early Christianity Illustrated by the Use of the Phoenix Motif," i: Florentino Garzía Martínez \& Gerard P. Luttikhuizen, eds., Jerusalem, Alexandria, Rome: Studies in Ancient Cultural Interaction in Honour of A. Hilhorst, Journal for the Study of Judaism Supplement Series vol. 82, Leiden: Brill, 147-164.

2005 "Paulus -en antikarismatisk karismatiker," i Povl Götke, Jonas Havelund \& Kristian Rasmussen, eds., Fra Buddha til Beckham, Odense: Syddansk Universitetsforlag, 45-65.

2009 "The Diversity of Apologetics: From Genre to a Mode of Thinking," i Anders-Christian Jacobsen, Jörg Ulrich \& David Brakke, eds., Critique and Apologetics. Jews, Christians and Pagans in Antiquity, Frankfurt am Main: Peter Lang, 15-41.

2011 "Påtvungen gavmildhed i 2 Korintherbrev," Dansk Teologisk Tidsskrift 1, 43-58.

2013 "Attaining Divine Perfection through Different Forms of Imitation," Numen 60 (1), 7-38. 
https://doi.org/10.1163/15685276-12341250

2014 "Fra tøsedreng til gudemand," Weekendavisen. Ideer 16.04, 1-2.

2015a "Apologetics," i: Robert A. Segal \& Kocku von Stuckrad, eds., Vocabulary for the Study of Religion. Vol. 1 A-E, Leiden: Brill, 110-114.

$2015 \mathrm{~b}$ "The use of historiography in Paul: A case-study of the instrumentalisation of the past in the context of Late Second Temple Judaism," i: Bernd-Christian Otto, Susanne Rau \& Jörg Rüpke, eds., History and Religion. Narrating a Religious Past, Religionsgeschichtliche Versuche und Vorarbeiten vol. 68, Berlin: DeGruyter, 63-92. https://doi.org/10.1515/9783110445954-005

2017 "At vandre i takt: om paraders og processioners rituelle betydning. Et durkheimsk perspektiv," Religionsvidenskabeligt Tidsskrift 66, 14-39. https://doi.org/10.7146/rt.v0i66.26446

2019 Testing Trust-Observing Obligation: Indexical Underpinnings of Symbolisation in 2 Corinthians (under udarbejdelse).

Pontoppidan, Henrik

1901 Lykke-Per. Hans store Værk. Bind V, København: Det nordiske Forlag.

1937 Lykke-Per 1-2, Optrykt efter Gyldendals Bibliotek vol. 20 i overensstemmelse med 4. udgave 1918, Gyldendals Tranebøger, København: Gyldendal.

Sampley, J. Paul

2003 "Paul and Frank Speech," i: idem, ed., Paul in the Greco-Roman World. A Handbook, Harrisburg, VA, London: Trinity Press, 293-318.

Sanderson, Stephen K.

2018 Religious Evolution and the Axial Age. From Shamans to Priests and Prophets, Scientific Studies of Religion. Inquiry and Explanation vol. 9, London: Bloomsbury.

Sloterdijk, Peter

2009 Du mußt dein Leben ändern. Über Anthropotechnik, Frankfurt am Main: Suhrkamp.

Turner, Jonathan H., Maryanski, Alexandra, Petersen, Anders Klostergaard og Geertz, Armin W.

2018 The Emergence and Evolution of Religion. By Means of Natural Selection, Evolutionary Analysis in Social Sciences vol. 1, New York og London: 2018.

Vergil

1996 Vergils Aeneide, oversat af Otto Steen Due, Aarhus: Centrum.

Wypustek, Andrzej

2012 Images of Eternal Beauty in Funerary Verse Inscriptions in the Hellenistic and Greco-Roman Period, Mnemosyne Supplement series 352, Leiden: Brill.

Anders Klostergaard Petersen, professor MSO, Afdeling for Religionsvidenskab, Aarhus Universitet 